\title{
The American Legal Dragon Awakens: Act Unethically, Expect Serious Pain
}

Linnea McCord, Pepperdine University, USA

Michael Magasin, Pepperdine University, USA

\begin{abstract}
Think it's unethical, but legal? Think again. Recent examples of draconian legal enforcement of ethical violations in American business indicate that the days of the "kindler, gentler" enforcement of ethical violations are coming to an end. We are entering the era of the American fire-breathing legal dragon of enforcement in which those caught acting unethically in business are likely to face severe legal punishment.
\end{abstract}

Keywords: ethics, business ethics, business law, enforcement

\section{INTRODUCTION}

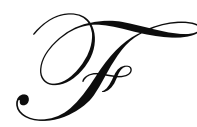

rom 1982 to 2000, the United States stock market experienced one of the longest economic booms in its history. Although the stock market fell precipitously from 2000-2002, it quickly recovered in the ensuring go-go years of the housing boom; hitting a new all-time high in 2007. During such a long period of rising personal financial fortunes, legal enforcement of ethical violations in business were few and sentences and penalties relatively light. After all, while the good times lasted, few voices are raised in complaint. In such an extended period of economic prosperity, it is easy for many Americans to misunderstand the pivotal role American law plays in enforcing ethical standards in American businesses and society.

Today's financial wipe-outs guarantee that legal enforcement of ethics will increasingly resemble a firebreathing dragon. In today's climate of skyrocketing foreclosures, millions of unemployed, multi-billion dollar Ponzi schemes, and trillions of dollars of taxpayer bailouts and guarantees, millions of angry citizens, investors, workers, and governments are not likely to be appeased by light sentences and penalties for those who violate their ethical responsibilities. Legal enforcement of ethical standards in today's environment of credit crisis and financial meltdown in the U.S. in likely to become much more painful than the "slap on the wrist" enforcement following the scandals of the 1980s and the 1990s. The days of the "kinder, gentler" legal enforcement of ethical standards is a thing of the past.

\section{MOUNTING ECONOMIC PAIN}

We are now experiencing one of the worst economic crises in the history of the United States. In 2006, the air began coming out of the housing bubble and home prices began to fall precipitously. One of the largest investment banks in the country, Bear Stearns, the smallest of the big five Wall Street investment banks, was the first one to fall in summer 2007. This is followed by Lehman Bros - the fourth largest and a 158 year old US investment bank - that went bust with $\$ 613$ billion in liabilities, of which $\$ 160$ billion was unsecured bonds held by investors globally. ${ }^{1}$ This precipitated one of the worst credit contractions in U.S. history and started the crisis of confidence in global financial markets.

The federal government has now doled out trillions of dollars in taxpayer bailouts, rescues and guarantees. Both Fannie Mae and Freddie Mac are now operating under conservatorships of the U.S. government, potentially putting American taxpayers on the hook for about $\$ 5$ trillion, nearly half of all U.S. mortgages. To avert the bankruptcy of American International Group, one of the largest insurance companies in the world, the U.S. government gave AIG more than $\$ 170$ billion and the credit default swaps will be moved off its balance sheet. In 
addition, billions more went to General Motors, Chrysler, Citigroup, Bank of America and other and commercial and investment banks

Currently, our federal government's debt is fast approaching $\$ 12$ trillion, an astonishingly high number considering that the GDP of the entire U.S. economy is around \$14 trillion. National unemployment has skyrocketed to $9.4 \%$, but in some areas of the country, unemployment is higher. In California almost $12 \%$ of the population is unemployed and the jobless rate in Las Vegas is now over 13\%. More than 6 million Americans are unemployed and millions more have already lost their homes. The annual federal debt has rocketed to $\$ 1.5$ trillion and trillion deficits are expected for years to come.

By the end of summer 2009, the Federal Deposit Insurance Corporation (FDIC) has taken over 81 banks, the largest number of bank failures since the savings and loans' failures in the late 1980s and early 1990s. Hundreds more banks are expected to fail shortly as commercial real estate loans, alt-A and option-arm mortgages, home equity loans, student loans, auto loans, and credit card debts continue to slip into delinquency and default. Home prices have plunged in many parts of the country, sometimes by as much as $40 \%$. U.S. stock markets are still down significantly from their all-time highs. For the first time in decades, Americans are facing an unfamiliar doublewhammy of staggering job losses as they watch the value of their assets, such as their homes and stock investments plummet. As the number and size of scandals mount, fear and rage are building in the country. Draconian legal enforcement against those who violate the laws of ethical conduct in American law is not likely to be far behind.

\section{OUR ETHICAL CONFUSION}

Over the past forty years, Americans have become confused about ethics, forgetting that in the U.S., morality, ethics and law are intimately intertwined. Our ethical confusion began in the late 1960s when the babyboomer generation came of age with the mantra "if it feels good do it" and "do your own thing." This Me Generation, raised in unparalleled peace and prosperity, rejected the notion of their depression and war parents that there were clear ethical standards of conduct, preferring instead the looser standards of ethics outlined in a 1966 book entitled "Situational Ethics: The New Morality". The guiding principle of situational ethics is that since every situation is different, no one code of morality (that is ethics) applies equally to every situation.

Over the ensuing decades, another new concept of ethics became popular in American universities that came to be known as relative ethics. This type of ethical analysis was an outgrowth of multiculturalism movement that swept across many U.S. campuses in the past several decades. Under the theory of relative ethics, the United States is no longer viewed through the lens of one culture, the American culture. Instead, the populations of the U.S. are viewed through the prism of multiple American sub-cultures, such as African-American, Hispanic and Asian and the like. When relative ethics is applied, each one of these self-described subcultures is credited with having its own distinctive code of moral conduct (ethics). Thus, according to this view of ethics, no one code of morality (ethics) can apply equally to all Americans.

The net result of situational ethics and relative ethics is that both ethics theories espouse the belief that there is no one universal code of ethical conduct that applies equally to all Americans. However, when ethics is viewed through the prism of American law, nothing could be further from the truth.

\section{MISUNDERSTANDING AMERICAN LAW}

Situational ethics and relative ethics conflict with how law operates in the U.S. To understand why, we must first review some basics of American law. The United States is a nation of laws, founded on the moral principle that all men are created equal. According to the Declaration of Independence, our inalienable rights to life, liberty and the pursuit of happiness flow directly from "the Creator", not through a monarch, pharaoh, emperor or any other human intermediary - a first in human history. The Constitution clearly lays out the structure of the federal government - including the executive, legislative and judicial functions. The first 10 amendments to the Constitution, the Bill of Rights, contain certain clearly described protections against the potentially abusive power of the federal government. These documents are the foundation of the American culture of law that applies equally to all Americans. ${ }^{2} \quad$ Our tradition of following the law predates the founding of the American Republic. The 
Mayflower Compact of 1620, signed by some of the earliest American settlers, said in pertinent part:

"Having undertaken for the Glory of God, and Advancement of the Christian Faith, and the Honour of our King and Country, a Voyage to plant the first Colony in the northern Parts of Virginia; Do by these Presents, solemnly and mutually, in the Presence of God and one another, covenant and combine ourselves together into a civil Body Politick, for our better Ordering and Preservation, and Furtherance of the Ends aforesaid: And by Virtue hereof do enact, constitute, and frame, such just and equal Laws, Ordinances, Acts, Constitutions, and Officers, from time to time, as shall be thought most meet and convenient for the general Good of the Colony; unto which we promise all due Submission and Obedience."

Equality before the law is a central premise of the American concept of Rule of Law. Thus, situational ethics that says a different ethical code applies to different situations is not true for those situations where American law applies. Under our Rule of Law, the same legal standard must be applied to the same situations. However, since the facts in each case are likely to be different, even though the exact same legal standard is applied equally, the individual facts of each case can, and of do, lead to different end results.

Relative ethics also is not possible under American law. The fundamental documents of American law the Declaration of Independence, the Constitution and the Bill of Rights. - apply to all Americans, regardless of their ethnicity or membership in a self-described subculture. There is no special exemption in American law for any other sub-culture's ethical standards if they are in violation of American law. As the pledge of allegiance to the flag of the United States says, we are "one nation, under God, indivisible, with liberty and justice for all."

\section{MISUNDERSTANDING ENFORCEMENT IN AMERICAN LAW}

It is not surprising that there is so much confusion about how American law works because we are currently drowning in sea of statutes and regulations, a propensity that began with the burgeoning of government agencies to handle environmental, civil rights, education, and energy issues beginning in the 1960s and 1970s. Today, Congress increasingly is faced with statutes that are more than 1000 pages long that members of Congress admit they do not even read before they vote. At least one member of Congress had admitted that even if he did read the 1000 page statute, he wouldn't be able to understand what it said without an attorney to interpret the language for him. ${ }^{4}$

This flood of statutes and regulations over the past four decades obscures the fact that the United States legal system is not one based on statutes and regulations. This type of legal system is called a civil law system, and it is most commonly found in Europe and Asia. In the civil law system, only the legislative body has the ultimate power to create law by passing statutes and regulations. The courts are relegated to interpreting these statutes and regulations; they cannot create law themselves.

The American legal system is completely different. It is a common law system of law based on the British system. In a common law system, the courts share power to create law with the legislature. American courts not only interpret the statutes and regulations passed by the legislature, they also make law themselves through the decisions they render in the cases before them. In addition, American judges also have the power to declare statutes passed by legislature unconstitutional. Thus, American courts are equal creators of law with the legislatures, subject to the checks and balances of the American system. For example, while Congress' laws can be overturned by the U.S. Supreme Court through the power of the Court to declare its statutes unconstitutional, Congress can overturn Supreme Court decisions by passing legislation overruling the U.S. Supreme Court. An example of this Congressional power was the Civil Rights Act of 1991, which specifically overturned seven U.S. Supreme Court employment law decisions of the 1980s.

Although judges in the U.S. are guided by prior case law decisions just as their brethren in other AngloSaxon based common-law countries are, American judges have significantly more freedom, independence and flexibility in creating law than judges in other common law countries. Under the American constitutional system, the judiciary $\mathrm{s}$ is an equal partner in the checks and balances regime established in the 1787 U.S. Constitution to ensure that the legislature and the executive branches of government would not become too powerful. ${ }^{5}$ Besides 
precedent the U.S. Supreme Court can also able take into account, social, political and economic factors when rendering its decisions. Thus, legal enforcement under American "judge-made" case law is more flexible, creative, innovative than the courts of last resort of other common law jurisdictions.

Another important difference in the American common law system is that unlike other common law countries where jury trials are reserved only for criminal trials, jury trials are possible in both civil and criminal trials in the U.S. Finally, enforcement in American law is impacted by the wide discretion many statutes give American judges when assessing penalties and fines. For example, under American copyright law, U.S. judges have discretion to assess penalties for each willful copyright violation from $\$ 750$ to $\$ 150,000$ per violation. Since every song that is illegally downloaded is a separate copyright violation, if 100 songs were involved, the judge would have the ability to assess anywhere from $\$ 75,000$ to $\$ 15$ million against the copyright violator.

For all of these reasons, during good economic times, American legal enforcement against those who violate the laws of ethical conduct in American business appears dormant or lenient. When this occurs, many businesspeople mistakenly believe that their unethical conduct will not be punished harshly. However, in serious economic downturn, the attitudes of judges and juries alike are likely to harden and the punishments meted out in a climate of economic misery is likely to be much less forgiving against those who violate American laws of ethical conduct.

\section{THE AMERICAN ENFORCEMENT LEGAL DRAGON}

Think of enforcement under American law like a dragon that lives in a dark cave. The dragon's purpose is to make sure that people playing outside the cave are playing according to established rules so that no one gets hurt. The dragon is always watching, always there, but the people playing in front of the cave are unaware of the dragon's presence because in the bright sunlight all they can see in the cave is darkness. Since the dragon is very still and watches silently, the players outside hear no noises coming from the cave either.

Rumors have circulated that a vicious dragon lives in the cave and that the dragon will do them grievous injury if the players break the rules. However, since the players have been playing for so long without seeing or hearing the dragon, they begin to doubt that the dragon really exists. Over time, some of the players become complacent and begin to break a few rules. When nothing happens to them, they break a few more rules. Eventually, the inevitable happens. One of the players is seriously injured and starts to scream loudly. When the screams get loud enough, the dragon rushes out breathing fire on the players who broke the rules. The dragon leaves a path of destruction behind it to remind the remaining players that following the rules of the game is mandatory, not optional.

Several recent examples sentences, penalties and judgments against recent business scofflaws indicate that the fire-breathing dragon of American legal enforcement is coming out of its cave. The first was the sentence of Walter Forbes, the former CEO of Cendant Corporation. The second was the judgment against Richard Scrushy, the former CEO of Healthsouth, and the third was the prison sentence and judgment recently issued against Bernard Madoff responsible for the largest Ponzi scheme in American history involving $\$ 65$ billion.

\section{WALTER FORBES}

Walter Forbes was the CEO of CUC International, a direct marketing operation that merged in late 1997 with Henry Silvermans's HFS, a franchising giant, to form Cendant Corporation. Cendant Corp. operated such companies as the Ramada hotels, Century 21 real estate brokerage firms and Avis Rent-a-Car. Almost immediately after the merger, serious accounting irregularities were discovered in the books of CUC. The top three financial executives of CUC - the former CFO, former controller and an accountant in charge of external reporting - plead guilty to criminal charges inflating the company's earnings by using a cheat sheet "with amounts CUC could fraudulently add from special merger reserves and other sources to its reported earnings..." 6 . Over more than ten years CUC's revenue was inflated by $\$ 500$ million and its earnings inflated by $\$ 252$ million. When the existence of the fraud was revealed in April 1998, Cendant's stock value dropped \$14 billion in one day. Federal prosecutors indicted Walter Forbes, the former CEO and E. Kirk Shelton, the former vice-Chairman of CUC “... in one of the 
biggest securities prosecutions ever brought by the Justice Dept." ${ }^{7}$ Forbes had been paid $\$ 47.5$ million in severance payments. Cendant Corp. later alleged in an arbitration proceeding to return the entire severance because he had more than $\$ 2$ million in expense account abuses. ${ }^{8}$

In 1998, Cendant Corp. settled a class action lawsuit spearheaded by two of the largest state pension in the country, one in California and the other in NY, along with the largest municipal pension fund in the country, which was in NY for $\$ 2.85$ billion. In 2005, former Vice-Chairman Kirk Shelton was sentenced to 10 years in prison and ordered to pay $\$ 3.3$ billion in restitution. After two hung juries, former CEO was convicted at the third trial and sentenced to 12 years 7 months in prison and ordered to pay $\$ 3.3$ billion in restitution, along with Kirk Shelton. ${ }^{9}$

\section{RICHARD SCRUSHY}

Richard Scrushy was the CEO of HealthSouth Corp., one of the country's largest healthcare providers about 50,000 employees and 1700 locations nationwide. Both Healthsouth and Scrushy were criminally charged with overstating the company's profits by $\$ 2.7$ billion. Because the company intent was not missing Wall Street analysts' earnings estimates, the financial executives of the company manipulated allowances in their financial statements. An allowance was the difference between what the company charged a patient and the amount it could collected from the patient's health care insurer. By manipulating these allowances improperly, the company would show higher earnings. As part of the scheme, the company's assets were overstated by $\$ 1.5$ billion. ${ }^{10}$ In 2001 , CEO Scrushy earned a salary of nearly $\$ 4$ million as well as a $\$ 6.5$ million bonus, and was paid salary and perks of as much as $\$ 40$ million in one year. In 2003, shares of HealthSouth Corp. lost $97 \%$ after the New York Stock Exchange sought to delist the company because of the accounting fraud allegations.

Fifteen HealthSouth executives plead guilty to criminal charges, including five former chief financial officers, a former treasurer, vice-presidents, an assistant vice-president, the former chief information officer, a former assistant controller. The CEO Richard Scrushy was fired and criminally indicted under the Sarbanes-Oxley Act of 2002, the only CEO thus far to be indicted under the new statute. Scrushy was acquitted on all criminal charges by a local Birmingham, Alabama jury. Less than a year later, prosecutors indicted Scrushy for paying the former Governor of Alabama $\$ 500,000$ for a seat on a hospital regulatory board. Both the former governor and Scrushy were convicted on the bribery charges and received a seven year prison sentence. After six years of legal fights, Scrushy has spent tens of millions of dollars on legal fees, costs and settlements. In June of 2009, Richard Scrushy was hit was a $\$ 2.88$ billion civil judgment in a lawsuit brought by HealthSouth shareholders, which was the largest financial penalty ever levied against a single executive. ${ }^{11}$

\section{BERNARD MADOFF}

Bernard Madoff, a money manager and former head of the Nasdaq stock exchange, perpetrated the longestlasting, most widespread and expensive Ponzi scheme in American history, estimated to involve at least $\$ 65$ billion. For nearly 20 years, Madoff took money from a wide spectrum of investors, including wealthy individuals, charities, as well as hedge funds, corporations and the like. Madoff was arrested in December 2008, after the stock market meltdown and plead guilty in March 2009. The bankruptcy trustee has sued more than six hedge funds and large investors who had withdrawn $\$ 10$ billion from Madoff's fund in the final months and years of the fraud. Madoff's fraud devastated thousands of investors, some of whom had invested their entire life savings with him and were totally wiped out financially. After Madoff's arrest, his investment clients discovered that he had not bought any of the blue-chip stocks and Treasury bills listed on their accounts over the past 13 years.

Within weeks of the Scrushy civil verdict, Madoff received a jail sentence of 150 years. While judges have issued increasingly long prison sentences for corporate crime, 25 years for the CEO of WorldCom and 24 years for the former CEO of Enron, this sentence is clearly much more severe. ${ }^{12}$ As part of his sentence, Madoff was also required to pay $\$ 170$ billion, far more money that the several billions of dollars assessed against either Walter Forbes or Richard Scrushy.

Clearly the courts are sending a message to American businesspersons and companies that serious business crimes will be treated with the harshest penalties possible. The fire-breathing American law dragon is awake and on the prowl. 


\section{AUTHOR INFORMATION}

Michael R. Magasin, Education: U.C.L.A. B.A. History \& Political Science (1965); U.C.L.A. Law School, J.D. 1968, Admitted to Calif. State Bar 1969 to present. Work Experience: Former Dep. D.A., L.A. Co. District Attorney's Office, 1973 to 1981. Last assignment, special investigations (investigations of public corruption \& crimes); Private Practice, 1981 to present (white collar crimes etc). Pepperdine University, School of Business, 1985 to 1990 -adjunct professor, full time: 1990 to present., associate professor. Military Service: Active duty-1969 to 1973, JAGC, CPT. Assigned 1970 to 1973, Staff \& Faculty, associate professor, Dept. of Law, U.S.M.A., West Point, NY. USAR, 1973 to $1998,301^{\text {ST }}$ Civil Affairs Unit-CPT., $78^{\text {th }}$ LSO- CDR, COL-ret., JAGC.

Dr. Linnea B. McCord is an Associate Professor of Business Law at the Graziadio School of Business and Management of Pepperdine University. Dr. McCord received a Bachelor of Arts degree from University of Sydney (including one year of law school at the University of Sydney Law School), a Juris Doctor degree from the University of Houston Law Center, and a Masters of Business Administration degree from the University of Texas at Austin.

\footnotetext{
${ }^{1}$ The Price of Failure, The Economist, Oct 4, 2008, p. 82

${ }^{2}$ See generally, Lawrence M. Friedman, A History of American Law, $3^{\text {rd }}$ ed., (New York: Simon \& Schuster, 2005); Matthew Spalding, The Enduring Principles of the American Founding, (Wash., D.C.: The Heritage Foundation, 2001); Taylor Jordan, The U.S. Constitution and Fascinating Facts About It, (Illinois: Oak Hill Publishing Co., 2008); Wolfe, Dow, Dobson and Nesteruk, Understanding the Law: Principles, Problems and Potentials of the American Legal System, (Minnesota, West Publishing Co., 1995)

3 The Avalon Project, Documents in Law, History, and Diplimacy, Yale Law School, http://avalon.law.yale.edu/17th_century/mayflower.asp, (accessed Aug. 24, 2009)

${ }^{4}$ Nicholas Ballasy, Conyers Sees No Point in Members Reading 1,000-Page Health Care Bill--Unless They Have 2 Lawyers to Interpret It for Them, CBS News Online, Jul 27, 2009, http://www.cnsnews.com/Public/Content/Article.aspx?rsrcid=51610, (accessed Aug. 9, 2009)

5 See, e.g., the Pregnancy Discrimination Act of 1978 and the 1991 Civil Rights Act which specially overruled certain U.S. Supreme Court decisions.

${ }^{6}$ Ann Davis, Ex-Chairman of Cendant is Indicted, Wall St. J., Mar. 1, 2001, p. A3

${ }^{7}$ David E. Rovella, SEC 'Goes Criminal' On Fraud, Nat'1 Law J., May 7, 2001, p. A1

${ }^{8}$ Cendant Case Scorecard: Government 3; Book-Cookers O, Fortune, Jul. 10, 2000, p. 42

${ }^{9}$ Zachart Hio

${ }^{10}$ Jonathan Weil, Accounting Scheme was Straightforward But aHard to Detect, Wall. St. J., Mar. 20, 2003, p. C1

${ }^{11}$ Valerie Bauerlein and Mike Esterl, Judge Orders Scurshy to Pay \$2.88 Billion in Civil Suit, Wall St. J., Jun. 19, 2009, p. B1

${ }^{12}$ Walter Hamilton, Tina Susman and Tom Petruno, A Strong Message to Wall Street, L.A. Times, June 30, 2009, p. A1
} 